International Research Journal of Management, IT \& Social Sciences
Available online at https://sloap.org/journals/index.php/irjmis/
Vol. 6 No. 5, September 2019, pages: 234 241
ISSN: 2395-7492
https://doi.org/10.21744/irjmis.v6n5.734

\title{
Destructive Testing Method for Specimen and Crystal Structure on Maximum Solubility
}

\author{
Sorrow George Manuel ${ }^{a}$ \\ Jack Santo Cross ${ }^{\text {b }}$ \\ David Mick Silvester ${ }^{\mathrm{c}}$ \\ Romano Proud Blour ${ }^{\mathrm{d}}$ \\ Janet Napolion Stagger ${ }^{\mathrm{e}}$
}

\section{Article history:}

Received: 27 March 2019

Accepted: 31 July 2019

Published: 04 September 2019

\section{Keywords:}

crystal structure;

destructive;

maximum solubility;

specimen;

testing method;

Author correspondence:

Sorrow George Manuel,

London School of Economics and Political Science, London, United Kingdom.

Email address: manuel.sg@lse.ac.uk

\begin{abstract}
From non-destructive testing, we have found various flaws in both specimens so no method in the universe is perfect but we can rectify the defects but cannot be removed completely. From destructive testing we have found that First specimen MS (MS) sustain stress without failure due its similar crystal structure $(\mathrm{BCC})$ on the other hand second specimen have failed within the lower stress range due to lack of cohesion, adhesion between the dissimilar metals MS and SS, and also both have different crystal structures BCC and FCC respectively. Thus, to gain maximum strength of weld bead, welding should be done using similar metals with maximum solubility.
\end{abstract}

2395-7492@ Copyright 2019. The Author. This is an open-access article under the CC BY-SA license (https://creativecommons.org/licenses/by-sa/4.0/) All rights reserved.

\section{Introduction}

Advancement in the manufacturing process is in progress since very old age as the human needs go on increasing. Welding is a process of joining two metal pieces by the application of heat. Welding is the least expensive process and widely used nowadays in fabrication. Welding is an essential part of everyday life (Bondar et al., 2011; Pathange et al., 2006). From cars to high rise office buildings, airplanes to rockets, pipelines to highways, none of it would be possible without welding. It is essential for young engineers to have very well knowledge of welding as this science has endless future with endless human needs that need to be quenched. There are various types of welding like Gas welding,

a London School of Economics and Political Science, London, United Kingdom

b University of Roehampton, London, United Kingdom

c University of Roehampton, London, United Kingdom

${ }^{d}$ University of Roehampton, London, United Kingdom

${ }^{\mathrm{e}}$ London School of Economics and Political Science, London, United Kingdom 
Arc welding, resistance welding, solid state welding and few more. In this report Tungsten Inert Gas welding has been covered in detail more specifically about the filler rods used in GTAW process. There needs the skills to produce a required weld joints with precision as if lacks in quality entire structure may fail (Suryanarayana, 2001; Vippagunta et al., 2001). The objective project is to study the influence of filler rods used in TIG welding process as it considerably affects the welded structure. Various testing like hardness, bending and Nondestructive testing (NDT) have been performed for different filler rods used and influences caused by filler rods have been studied and conclusions are noted.

\section{Materials and Methods}

The project entitled Influence of filler rods in Tungsten Inert gas welding is to understand and analyze which filler rods should be selected to best suit the welding process exclusively for joining Mild Steel plates. In our course of the project we will be using two kinds of filler rods Mild steel of diameter $2.5 \mathrm{~mm}$ and Stainless steel of diameter $2 \mathrm{~mm}$. Two kinds of tests will be performed, destructive and nondestructive testing. All the necessary mechanical parameters like stress, strain, hardness, etc. will be calculated and best possible conclusion will be documented at the closing of this document (Mehra \& Jackson, 2013; Karim et al., 2000).

The research on Experimental Analysis of Effect of Different Filler Rods on Mild Steel by Shielded Metal Arc Welding, he used Parent metal as Mild steel and welding using three filler rods Austenite stainless steel, Ferrite stainless steel and Mild steel for 60 degrees groove butt joint and analysis has been done using Hardness and Tensile test (Drapier-Beche et al., 1997; He et al., 1995).

Finally, we have done the welding of plates and it would be further carried for testing those are non-destructive as well as destructive testing to understand and analyze its capability and suitability in real-world applications. Liquid penetrates testing Inspection is then performed under appropriate lighting to detect indications from any flaws which may be present. After doing the testing we have made the observations from both the destructive and nondestructive testing. And we refer first specimen as mild specimen welded with MS as filler rod and second specimen as specimen for the mild steel specimen welded with SS as filler rod (Shah et al., 2006; Flores et al., 2007).

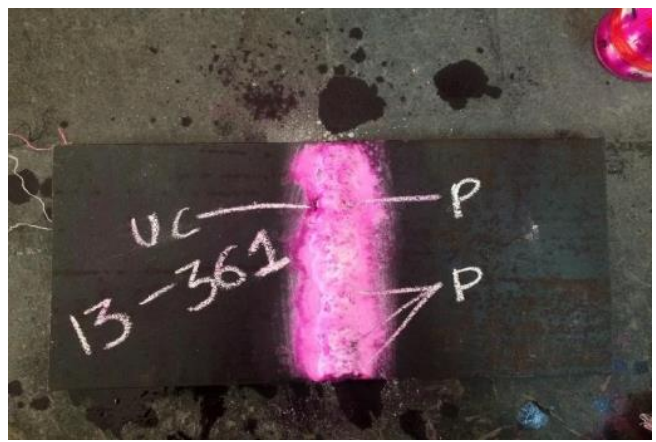

Figure 1. Inspection of weld for MS as filler rod

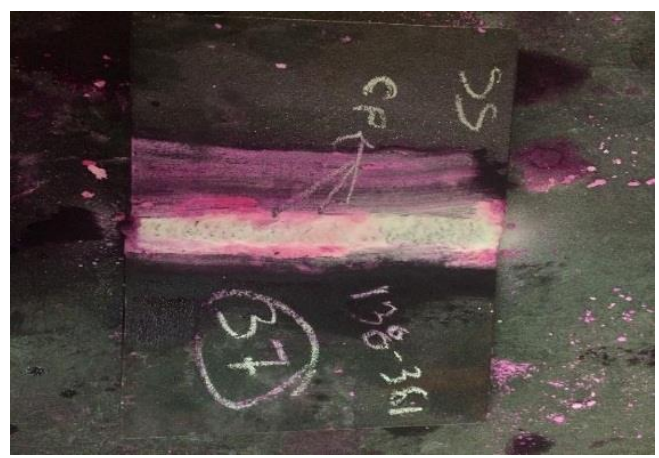

Figure 2. Inspection of weld for SS as filler rod

Manuel, S. G., Cross, J. S., Silvester, D. M., Blour, R. P., \& Stagger, J. N. (2019). Destructive testing method for specimen and crystal structure on maximum solubility. International Research Journal of Management, IT and Social Sciences, 6(5), 234-241. https://doi.org/10.21744/irjmis.v6n5.734 
Liquid Penetrate Testing: Surface flaws have been observed on both specimens using Penetrant testing which includes porosity and undercuts and the first specimen has more defect when compared to second specimen. And caused due to lack of fusion and more current fluctuations.

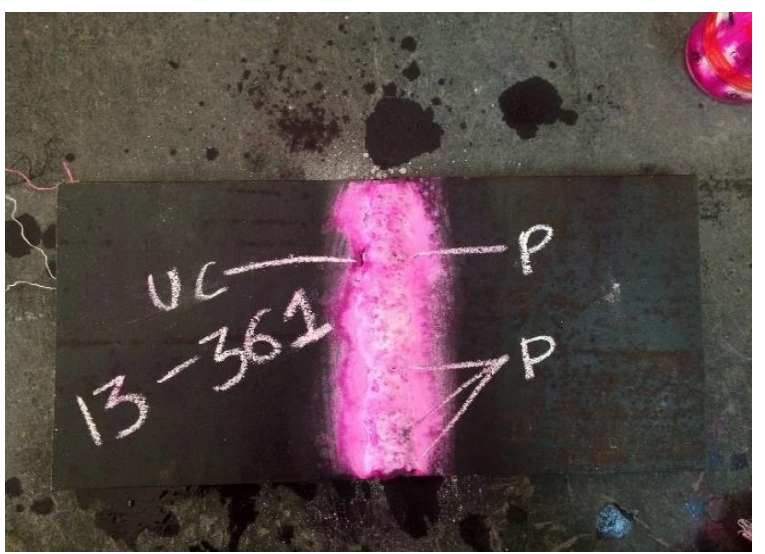

Figure 3. Observation of LPT

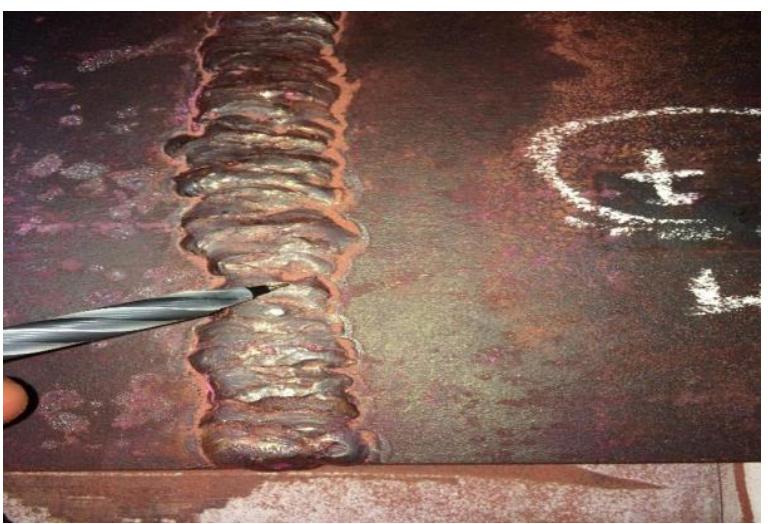

Figure 4. Observation of MPI

Magnetic Particles Testing: It has been found various porosity and undercuts within the surfaces of both specimens. In defected portions, ferromagnetic particles have been gathered as shown in figures.

Radiographic Inspection: Various flaws have been observed in welding as we got the image on radiographic film and report caused due to lack of fusion.

Hardness Test: In this test we observed hardness in the weld zone of the first specimen has been increased as mild steel has been used as filler rod and for the second specimen hardness has been decreased as SS used as filler which has less hardness than the parent joining plates. It can be observed from graph and tables.

Table 1

SS filler on distance

\begin{tabular}{|l|l|l|l|l|l|l|l|}
\hline Distance in Cm & 0 & 1 & 2 & 3 & 4 & 5 & 6 \\
\hline HRC for MS as filler (RHN) & 79 & 85 & 89 & 91 & 88 & 85 & 78 \\
\hline HRC for SS as filler (RHN) & 70 & 79 & 80 & 60 & 83 & 80 & 77 \\
\hline
\end{tabular}




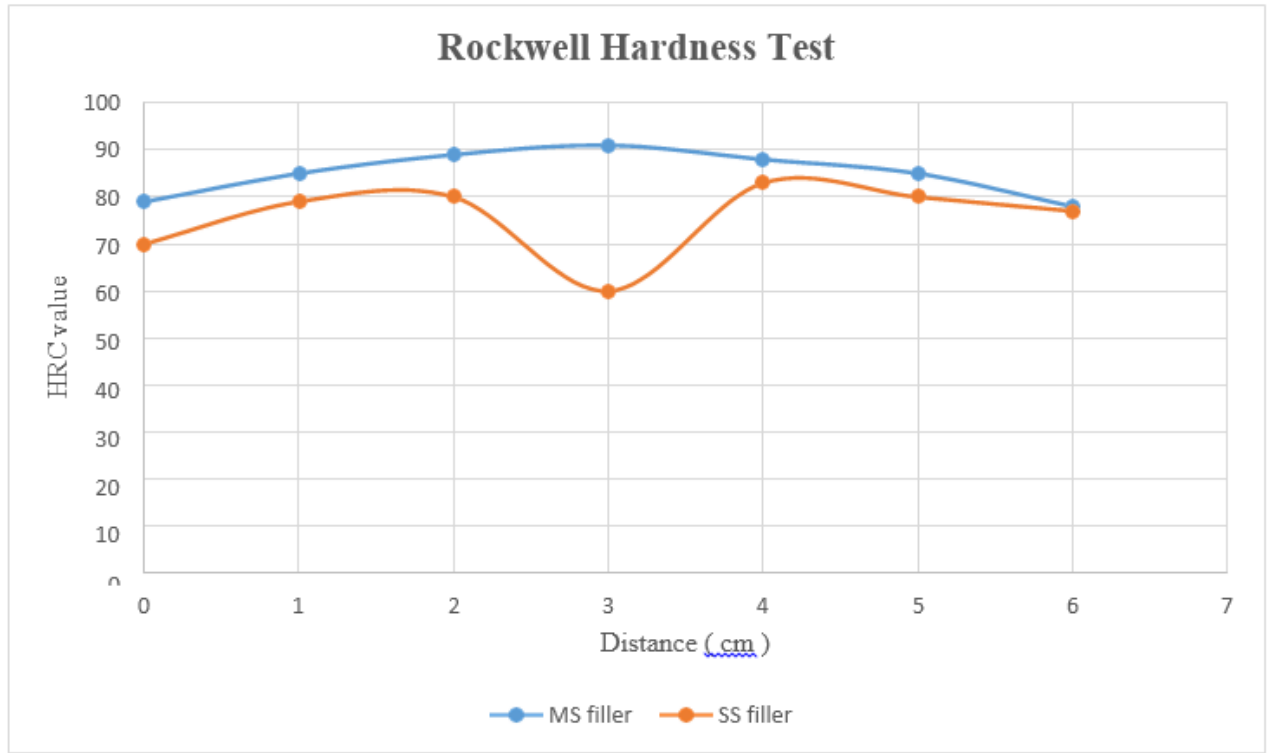

Figure 5. Showing Rockwell hardness test graph

Bend Test: We observed that as steel is less hard and malleable than mild steel. First specimen MS (MS) sustains bending load whereas second specimen MS (SS) broken off during bending. In graph blue color line represents the first specimen and orange color represents second specimen. As shown in graph and tables.

Table 2

Bend test of the first specimen

\begin{tabular}{|l|l|l|l|l|l|l|l|l|l|}
\hline Load (KN) & 5 & 7 & 10 & 12 & 13 & 13.5 & 14.5 & 15 & 16 \\
\hline Deflection (mm) & 5 & 7.5 & 10 & 17.5 & 25 & 35 & 42.5 & 60 & 70 \\
\hline
\end{tabular}

Table 3

Bend test of the second specimen

\begin{tabular}{|l|l|l|l|l|l|l|l|l|l|}
\hline Load $(\mathrm{KN})$ & 5 & 8 & 10 & 10.5 & 11 & 12 & 13 & 13.5 & 15 \\
\hline Deflection $(\mathrm{mm})$ & 5 & 10 & 20 & 27.5 & 32.5 & 40 & 47 & 52.5 & 70 \\
\hline
\end{tabular}

Manuel, S. G., Cross, J. S., Silvester, D. M., Blour, R. P., \& Stagger, J. N. (2019). Destructive testing method for specimen and crystal structure on maximum solubility. International Research Journal of Management, IT and Social Sciences, 6(5), 234-241. https://doi.org/10.21744/irjmis.v6n5.734 


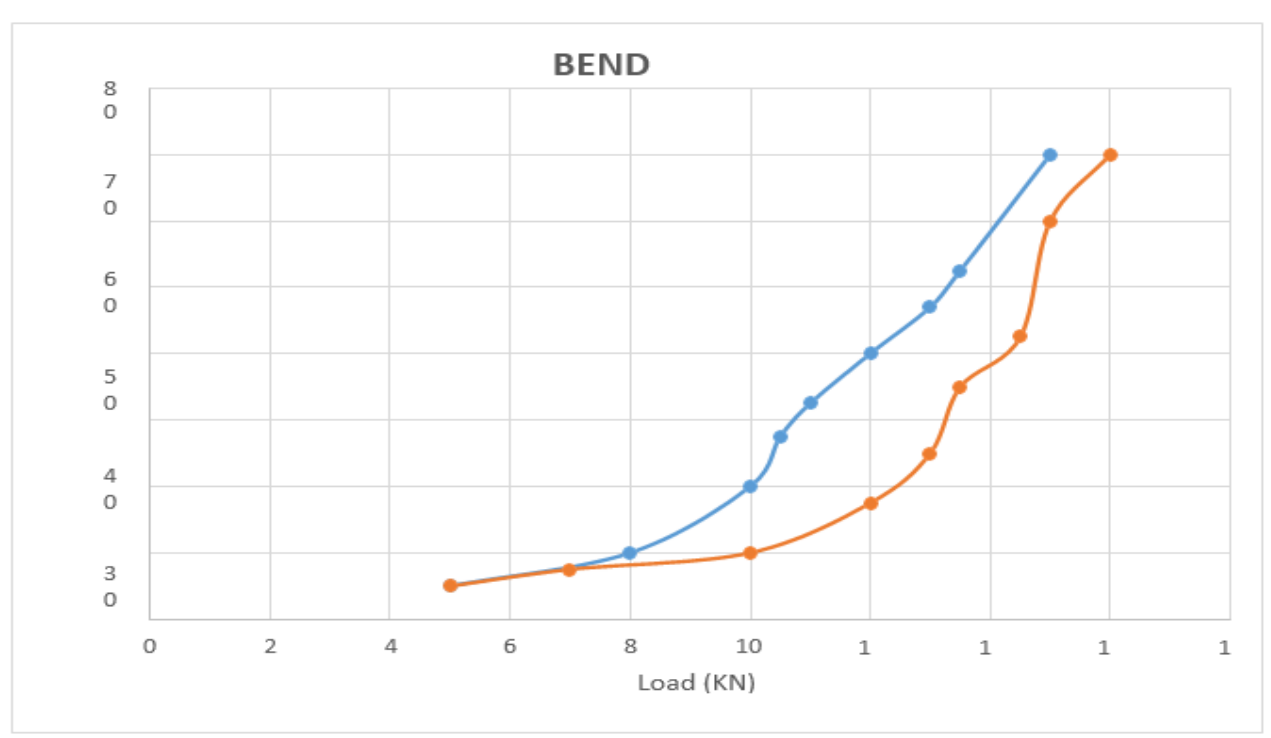

Figure 6. Graph of Bend test

From the graph, it is to be noted that blue color line represents the first specimen and orange color represents second specimen bending curve.

Tensile Test: It is observed that first specimen MS (MS) has been broken at the point near to edge of base metal as weld bead is stronger, whereas for second specimen MS (SS) it has found that it has been broken at weld bead as it is weaker than the parent metal. It has been shown in tables and graph.

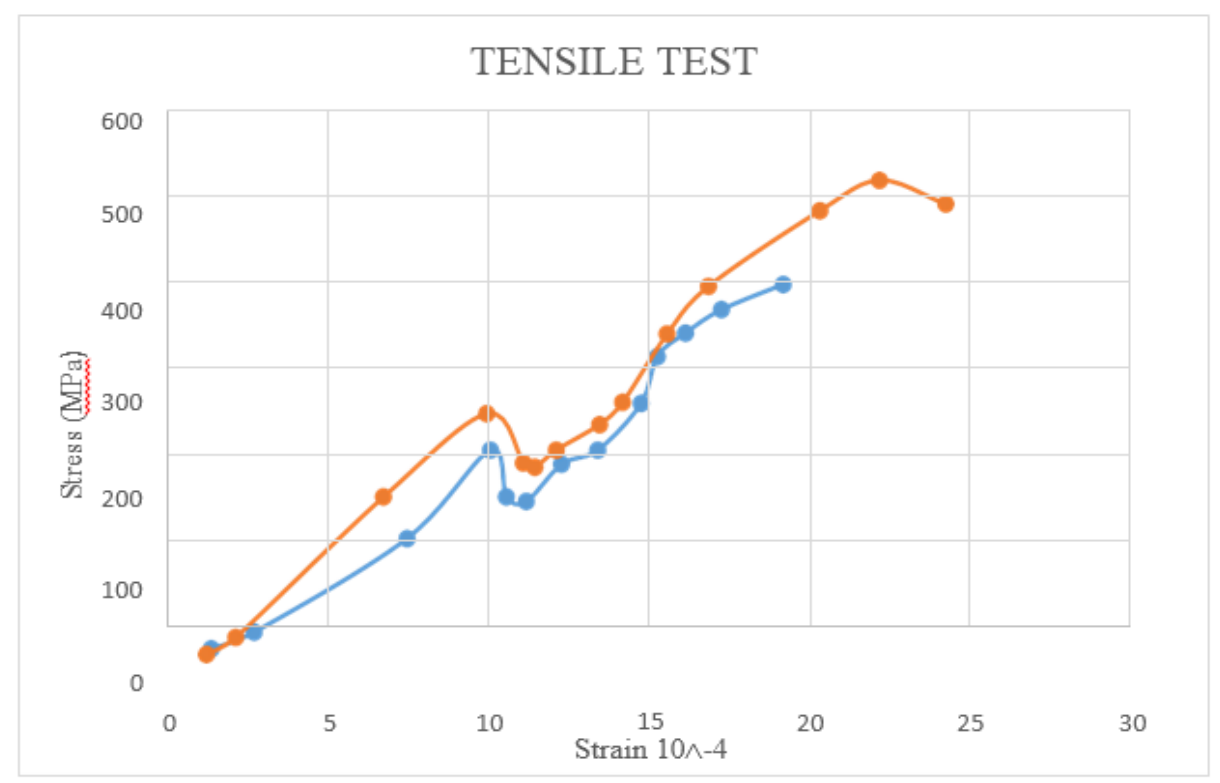

Figure 7. Graph of Tensile test 
Table 4

Readings of tensile test

\begin{tabular}{llll}
\hline $\begin{array}{l}\text { Stress of first } \\
\text { Specimen ( MPa) }\end{array}$ & $\begin{array}{l}\text { Strain of first } \\
\text { specimen* } 10^{-3}\end{array}$ & $\begin{array}{l}\text { Stress } \square 2 \text { of second } \\
\text { specimen }(\mathrm{MPa})\end{array}$ & $\begin{array}{l}\text { Strain e2 of second } \\
\text { specimen *10 } 1-3\end{array}$ \\
\hline 31.5 & 1.15 & 37.7 & 1.3 \\
50 & 2.06 & 55.55 & 2.64 \\
200 & 6.67 & 155.5 & 7.4 \\
289 & 9.89 & 250 & 10 \\
236.3 & 11.03 & 200 & 10.5 \\
231.6 & 11.38 & 195 & 11.12 \\
250 & 12.05 & 235 & 12.22 \\
277.3 & 13.4 & 250 & 13.35 \\
301.1 & 14.12 & 300 & 14.7 \\
374.09 & 15.51 & 350 & 15.2 \\
425.06 & 16.8 & 375 & 16.08 \\
505.67 & 20.27 & 400 & 17.2 \\
538 & 22.13 & 425 & 19.13 \\
512.8 & 24.19 & & \\
\hline
\end{tabular}

It has been observed that first specimen break at 512.8 MPa and second specimen break at $425 \mathrm{MPa}$, as hardness and strength of former, is more than later.

\section{Results and Discussions}

From non-destructive testing, we have found that there have been various flaws like porosity, lack of fusion and undercuts in the weld joints of both the specimen due to:

a) Low heat input.

b) Incorrect voltage and inductance.

c) Improper welding positions.

d) Wrong weld bead orientations.

e) Presence of moisture in the gas.

f) Weld nozzle has been held too far from the workpiece.

g) Improper torch angle.

h) Presence of grease oil on the base metal surface.

\section{Conclusion}

Following are the conclusions we have got from our project have been written in point below:

a) From non-destructive testing, we have found various flaws in both specimens so no method in the universe is perfect but we can rectify the defects but cannot be removed completely.

b) From destructive testing we have found that First specimen MS (MS) sustain stress without failure due its similar crystal structure (BCC) on the other hand second specimen have failed within the lower stress range due to lack of cohesion, adhesion between the dissimilar metals MS and SS, and also both have different crystal structures BCC and FCC respectively.

Thus, to gain maximum strength of weld bead, welding should be done using similar metals with maximum solubility.

\section{Conflict of interest statement}

The authors declared that they have no competing interest.

\footnotetext{
Manuel, S. G., Cross, J. S., Silvester, D. M., Blour, R. P., \& Stagger, J. N. (2019). Destructive testing method for specimen and crystal structure on maximum solubility. International Research Journal of Management, IT and Social Sciences, 6(5), 234-241. https://doi.org/10.21744/irjmis.v6n5.734
} 
Statement of authorship

The authors have a responsibility for the conception and design of the study. The authors have approved the final article.

Acknowledgments

The authors would like to thank the editor of IRJMIS for their valuable time, support, and advice in completing the present research. 


\section{References}

Bondar, D., Lynsdale, C. J., Milestone, N. B., Hassani, N., \& Ramezanianpour, A. A. (2011). Effect of heat treatment on reactivity-strength of alkali-activated natural pozzolans. Construction and Building Materials, 25(10), 40654071. https://doi.org/10.1016/j.conbuildmat.2011.04.044

Drapier-Beche, N., Fanni, J., Parmentier, M., \& Vilasi, M. (1997). Evaluation of lactose crystalline forms by nondestructive analysis. Journal of Dairy Science, 80(3), 457-463. https://doi.org/10.3168/jds.S00220302(97)75957-5

Flores, S., Famá, L., Rojas, A. M., Goyanes, S., \& Gerschenson, L. (2007). Physical properties of tapioca-starch edible films: Influence of filmmaking and potassium sorbate. Food Research International, 40(2), 257-265. https://doi.org/10.1016/j.foodres.2006.02.004

He, C., Osbaeck, B., \& Makovicky, E. (1995). Pozzolanic reactions of six principal clay minerals: activation, reactivity assessments and technological effects. Cement and concrete research, 25(8), 1691-1702. https://doi.org/10.1016/0008-8846(95)00165-4

Karim, A. A., Norziah, M. H., \& Seow, C. C. (2000). Methods for the study of starch retrogradation. Food chemistry, 71(1), 9-36. https://doi.org/10.1016/S0308-8146(00)00130-8

Mehra, O. P., \& Jackson, M. L. (2013). Iron oxide removal from soils and clays by a dithionite-citrate system buffered with sodium bicarbonate. In Clays and clay minerals (pp. 317-327). Pergamon. https://doi.org/10.1016/B978-008-009235-5.50026-7

Pathange, L. P., Mallikarjunan, P., Marini, R. P., O’Keefe, S., \& Vaughan, D. (2006). Non-destructive evaluation of apple maturity using an electronic nose system. Journal of Food Engineering, 77(4), 1018-1023. https://doi.org/10.1016/j.jfoodeng.2005.08.034

Shah, B., Kakumanu, V. K., \& Bansal, A. K. (2006). Analytical techniques for quantification of amorphous/crystalline phases in pharmaceutical solids. Journal of pharmaceutical sciences, 95(8), 1641-1665. https://doi.org/10.1002/jps.20644

Suryanarayana, C. (2001). Mechanical alloying and milling. Progress in materials science, 46(1-2), 1-184. https://doi.org/10.1016/S0079-6425(99)00010-9

Vippagunta, S. R., Brittain, H. G., \& Grant, D. J. (2001). Crystalline solids. Advanced drug delivery reviews, 48(1), 326. https://doi.org/10.1016/S0169-409X(01)00097-7

Manuel, S. G., Cross, J. S., Silvester, D. M., Blour, R. P., \& Stagger, J. N. (2019). Destructive testing method for specimen and crystal structure on maximum solubility. International Research Journal of Management, IT and Social Sciences, 6(5), 234-241. https://doi.org/10.21744/irjmis.v6n5.734 